Formal compensation practices in family SMEs

Peer-reviewed author version

MICHIELS, Anneleen (2017) Formal compensation practices in family SMEs. In:

Journal of small business and enterprise development, 24(1), p. 88-104.

DOI: 10.1108/JSBED-12-2015-0173

Handle: http://hdl.handle.net/1942/23009 


\section{Formal Compensation Practices in Family SMEs}

\section{Introduction}

When asked about the main challenges they are facing, small and medium-sized enterprises (hereafter: SMEs) often point to human resource concerns (Heneman et al., 2000; McCann et al., 2001). More specifically, compensation issues are frequently indicated as a significant concern (Cardon \& Stevens, 2004; Rutherford et al., 2003). For family firms, which represent the majority of the SMEs (Astrachan \& Shanker, 2003), compensation issues are particularly important, since "compensation is at the heart of more family-business questions than any other topic except succession" (Aronoff et al., 2011, p. 3).

Despite the clear importance of this matter for family SMEs, academic interest has been rather limited (Astrachan, 2010; Cruz et al., 2011) and the available literature appears to be rich in recommendations, but limited in sound descriptive surveys or analytical research (Heneman et al., 2000; Sels et al., 2006). The scant amount of research that examines compensation in family SMEs mainly focuses on the level of employee (Carrasco-Hernandez \& Sanchez-Marin, 2007) or CEO (Michiels et al., 2013) compensation rather than the compensation function itsel. This mismatch in practitioner concerns and academic research has led to a number of calls for research on HRM and compensation issues in small and mediumsized family businesses (Astrachan, 2010; Heneman et al., 2000; Sharma, 2004). After all, family firms are an important subgroup of SMEs, as they possess some peculiar characteristics that are different from those of nonfamily SMEs, which can cause family firms to evaluate, acquire, bundle and leverage their resources in ways that are significantly different from those of nonfamily firms (Sirmon \& Hitt, 2003).

In an attempt to respond to these calls, the present study investigates the formalization of compensation practices in family SMEs. Drawing on previous literature (Aronoff et al., 2011; De Kok \& Uhlaner, 2001; Kim \& Gao, 2010; Kotey \& Slade, 2005; Nguyen \& Bryant, 2004), the word formal in this study refers to the documentation and regular application of procedures and best practices.

Adopting formal compensation practices in family SMEs might be important in at least two ways. First, the compensation system can be an important communication device to foster entrepreneurial activities and to signal legitimacy to external stakeholders (Cardon \& Stevens, 
2004; Graham et al., 2002). For instance, private family firms must compete with large and international companies for talented employees. Adopting more formal compensation practices might therefore be a sign of professionalization and thus make the firm more attractive to potential applicants. Additionally, SMEs with low level of formal HR (and thus also compensation) practices are not considered as attractive loan applicants by senior credit officers (Nguyen \& Bryant, 2004). In order to qualify for loans from financial institutions, formalizing compensation procedures thus might be an important aspect for family SMEs. Second, SMEs are recently beginning to recognize the benefits that the implementation of formal HRM practices can bring (Sheehan, 2014) because implementing HRM best practices generally leads to higher firm performance (Carlson et al., 2006; Hayton, 2003; Hornsby \& Kuratko, 2003; Kotey \& Slade, 2005; Sels et al., 2006; Sheehan et al., 2014). By investigating the use of formal compensation practices in family SMEs, this study aims to provide important new insights in these issues for academics, as well as family business practitioners, prospective applicants and financiers of family businesses. Moreover, this study includes a contingency that allows to explore heterogeneity across family businesses in their use of formal compensation practices: the CEO type. The overall research question of this study therefore is the following: "Do family SMEs engage in formal compensation practices, and are there differences between types of family firms?"

Using a sample of 124 small to medium-sized Belgian family firms, the results of this study suggest that formal compensation practices are quite common in Belgian family SMEs. Next, the findings support the suggestion based on managerial ability and agency arguments, that family firms with a family CEO adopt significantly less formal compensation practices than their counterparts that are led by a nonfamily CEO. This study makes a number of contributions to the academic literature. First, this study contributes to the current debate on family business professionalization (Dekker et al., 2013; Stewart \& Hitt, 2012; Songini, 2006) by investigating the impact of CEO status (family versus nonfamily) on one aspect of HR professionalization in detail. Second, while prior research on formal HR practices is scarce and mainly compares family and nonfamily SMEs (e.g. Reid et al., 2001; Reid et al., 2002), this paper takes into account different types of family SMEs by distinguishing between firms with family and nonfamily CEOs. Hereby, this paper addresses recent calls for researchers to focus on the heterogeneous nature of family businesses, thereby going beyond comparisons between family and nonfamily businesses (Chua et al., 2012; Nordqvist et al, 2014). Third, this paper may also be of interest to family business practitioners and consultants, as it provides 
insight in the actual use of formal compensation practices that are recommended as a best practice in numerous practitioner handbooks.

The layout of this paper is as follows. The next section gives a brief overview of the existent literature on formal compensation practices and the hypothesis is developed. Thereafter, the methodology of the data collection is explained and some general characteristics of the sample firms are presented. In the next section, the hypotheses are tested via regression analyses and results are discussed. The final section concludes.

\section{The adoption of formal compensation practices in family SMEs}

Formalizing compensation practices in family SMEs can have advantages as well as disadvantages. On the one hand, formality can be considered as a positive thing by employees because it increases feelings of fairness and consistency among employees, which is central to gaining their commitment to the firm (Marlow \& Patton, 2002; Wilkinson, 1999). On the other hand, introducing formalized compensation practices can also have disadvantages for the family businesses. For example, the high cost associated with these practices might be a burden for smaller family firms with limited resources. Formalizing the compensation function might also limit the possibility for employees to negotiate on their salary and benefits, which might decrease their motivation (Marlow \& Patton, 2002). Additionally, formalizing the compensation function might undermine the advantages of having an informal culture.

Previous empirical studies on the implementation of formal HRM practices in family firms have compared them to nonfamily firms. While some studies found that family firms are less likely to adopt formal HRM practices than their nonfamily counterparts (Astrachan \& Kolenko, 1994; de Kok et al., 2006; Reid \& Adams, 2001; Reid et al., 2002), others found no significant influence of family ownership on the use of formal HRM practices (Newman \& Sheikh, 2014; Wu \& Hoque, 2014). No study to date has taken into account aspect the heterogeneity of family firms by investigating differences in formal HRM practices between types of family firms. Yet, as the differences among family firms might be as great as (or even greater than) the differences between family and nonfamily firms (Chua et al., 2012), this might explain inconclusive results of previous studies which considered family firms as an homogenous group. By taking into account a contingency that allows to explore heterogeneity across family SMEs, this study aims at providing some insights into the use of formal compensation practices in family SMEs. 


\section{The impact of CEO family status on the adoption of formal compensation practices}

In private family firms, most important decisions are taken by the CEO (e.g. Harris \& Ogbonna, 2007). Also the occurrence of formalization in SMEs depends for a large part on the recognition of the CEO of the need for delegation and formalization of that task (Barrett \& Mayson, 2007; Marlow, 2002). The CEO may therefore play an important role in facilitating the formalization process of the compensation function. In order to investigate possible differences in the extent to which a CEO impacts the level of formalization of the compensation function in family firms, this study distinguishes between firms which are led by a member of the controlling family ( a family $C E O$ ) and firms which are led by an external manager ( $a$ nonfamily $C E O$ ). After all, a significant percentage of private family firms are managed by nonfamily CEOs (Bennedsen et al., 2007; Bloom \& Van Reenen, 2007) and the difference in CEO identity (family versus nonfamily CEO) represents a significant factor explaining strategy and performance differentials among family firms (Miller et al., 2013; Zona, 2016).

Previous research found that nonfamily CEOs are more inclined to implement professional management practices than family CEOs (Dyer, 1989; Sonfield \& Lussier, 2009). The arguments used in this study for examining differences of family versus nonfamily CEOs regarding the formalization of the compensation function can be categorized into two groups: managerial ability arguments and agency arguments.

First, some studies indicate that SMEs seem to be less able to adopt formal HRM practices as compared to larger firms due to the lack of managerial expertise (Bartram, 2005; Hill \& Stewart, 2000). Several scholars have examined possible differences between the managerial ability of family versus nonfamily CEOs in family firms. They found that the professional ability of non-family CEOs in general is higher than the professional ability of most family CEOs (Bertrand \& Schoar, 2006; Bloom \& Van Reenen, 2007). Nonfamily CEOs are found to provide extremely valuable services to the firms they head, and are found to be more educated and experienced than their family counterparts (Bennedsen et al., 2007). Additionally, they are more often educated in classrooms where formal and generic skills are taught (Dyer, 1989). Thus, as appointing a nonfamily CEO generally leads to an increase in managerial expertise, knowledge and competence (Miller et al., 2013, 2014; Zona, 2016), firms with nonfamily CEOs are expected to implement more formal compensation practices because these CEOs are more able to do so. 
Second, family firms with a nonfamily CEO are found to be associated with substantially different agency costs than family firms with a family CEO. As implementing formal control systems is a way in which firms can mitigate agency costs (Jensen \& Meckling, 1976; Myers, 1977; Fama \& Jensen, 1983), and the agency costs faced by family firms with a family CEO and those with a nonfamily CEO differ, the adoption of formal compensation systems might also differ between these two types of firms. Since a nonfamily CEO typically holds no or little ownership of the firm, type I (owner-manager) agency problems can occur (Jensen \& Meckling, 1967). Family owners may therefore push the CEO to formalize processes in order to decrease possible agency costs related to information asymmetries (e.g. having a written compensation policy instead of an informal, unclear policy which can be adjusted by the CEO to his or her consent). Additionally, family owners will probably need more detailed information about the business when the firm is led by a nonfamily CEO than when the CEO is a member of the family. They are therefore more likely to require written documents and formalized processes when a nonfamily CEO leads the firm. Also, they may try to increase their involvement and influence in the firm by discussing the compensation policy in the family forum or formulating compensation rules in the family charter.

Although research has also indicated that information asymmetries are lower in case of a family CEO, and altruism may be an advantage of family ownership, family CEOs cannot be considered as perfect agents (Jensen, 1994). Problems related to self-control and asymmetric altruism (e.g. shirking or free riding) that have been identified in private family firms (Chrisman et al., 2007; Chua et al., 2009) can result in unfair and disproportionate compensation packages for family employees vis-à-vis nonfamily employees. Yet, agency costs related to information asymmetries are expected to be much lower than in case of a nonfamily CEO. Additionally, family CEOs, in contrast to nonfamily CEOs, generally have a fair amount of tacit knowledge of the family business and its unwritten rules and informal culture (Cruz et al., 2010; Gomez-Mejia et al., 2001; Hall \& Nordqvist, 2008; Miller et al., 2009; Miller et al., 2014). Especially in smaller firms, this intimate knowledge of operations of the firm minimizes agency costs due to information asymmetries (Miller et al., 2014) and is thus expected to decrease the need to formalize several processes, including the compensation function ${ }^{1}$.

\footnotetext{
${ }^{1}$ This advantage is likely to only hold in SMEs, and not in larger firms. After all, the larger the firm, the more complex its administrative processes, and the higher the need for formalized procedures, which surpass the benefits of the tacit knowledge that family CEOs may possess (Miller et al., 2009).
} 
Based on both the managerial ability and agency arguments above, it can be expected that family firms with a nonfamily CEO will adopt more formal compensation practices than family firms with a family CEO. Put formally:

H1: Family firms with a nonfamily CEO adopt more formal compensation practices than family firms with a family CEO

\section{Method}

\section{Sample and data collection}

This study uses data from two different sources. The primary source of data is derived from a wider cross-sectional survey, conducted in 2012. Data was collected by means of an internet survey sent to Flemish (situated in the Dutch-speaking part of Belgium) privately-held firms. Given the normal restrained enthusiasm of businesses in general, and private family firms in particular, to give confidential information to outsiders, the survey was conducted in cooperation with one of the leading Belgian employers' associations. As privately-held firms are extremely secretive when it comes to compensation information (Jensen and Murphy, 1990), this approach should help to collect this sensitive information.

The association provided us with a mailing list of 1028 Flemish privately-held firms. Before distributing the internet survey, a copy was sent to the directors of the employers' association, who reviewed the survey and suggested a few modifications to enhance the understanding of the questions. After that, a pilot test was carried out with two firms and with several academic colleagues. This pilot test resulted in some rephrasing, adding a few extra options for answering selected questions, and expanding the questionnaire with other relevant questions. The questionnaire was finally distributed via email to the target group of 1028 companies, all of which are members of the employers' association. The focus of this research is on the compensation practices of private family firms. However, it is difficult to ex-ante determine whether a firm can be classified as a family firm or not. Therefore, this initial group of 1028 companies contains both family and nonfamily firm.

Because of the sensitivity of the information that was asked for in the questionnaire, and in order to boost the response rate, the email was sent from the employers' association email address. For each region, the email was addressed to the firm's CEO and accompanied by a cover letter from the regional chairman. This letter explained the aim of the survey, 
encouraged the CEOs to participate and included a hyperlink to the website containing the questionnaire. Persons that participated in the research and completely filled in the questionnaire, would receive a complimentary research report with the main results. While this approach will plausibly lead to a higher response rate, the cooperation with the employers' association could possibly cause a bias in the sampling. That is, as these firms are a member of the employers' association, they might be more eager to learn from colleagues and therefore more open to academic research. However, this approach has been adopted in other studies as well (e.g. Berent-Braun \& Uhlaner, 2012; Eddleston et al., 2008; Ling \& Kellermanns, 2010) and it has the advantage of reaching firms more willing to participate in research.

The initial email was sent in February 21, 2012. Subsequently two reminder-emails were sent to the firms that had not started or completed the questionnaire. A total of 246 questionnaires were received by the closing date of April 2, 2012, representing a response rate of nearly $25 \%$. Seen the profoundness of the survey and the sensitivity of the questions, together with the secretive nature of family firms (Neubauer \& Lank, 1998), this can be considered a very good response rate. This response rate is also higher than previous studies of privately-held firms that target CEOs (Michiels et al., 2015; Sheehan et al., 2014).

As the focus of this study is on small and medium-sized firms, all privately-held firms with up to 250 employees are included. Finally, all family firms were identified in the sample, using two questions from the survey. A firm is considered to be a family firm when (a) more than $50 \%$ of the shares were owned by one family, and/or (b) the CEO considered the firm to be a 'family firm' (Dyer, 2003; Westhead \& Cowling, 1998). After omitting nonfamily firms and firms that did not completely filled in all the variables of interest, final sample size consists of 124 family SMEs.

In order to assess potential non-response bias, differences between early and late respondents were tested, as late respondents are more similar to non-respondents (Kanuk \& Berenson, 1975; Oppenheim, 2000). As suggested by Wallace and Mellor (1988) and Graham and Harvey (2001), firms that returned the survey before a first reminder were classified as 'early respondents', and the other group as 'late respondents'. After all, the firms that did not reply to the initial email can be thought of as a sample from the nonresponse group, in the sense that they did not completed the survey until we bothered them further with a reminder. Several key firm characteristics were compared (such as firm size, age, sector and profitability) between the two groups, using Kruskal-Wallis tests. No statistical significant differences are found, which suggests that non-response bias does not appear to pose a major problem in our study. 
The secondary source of data is the 2011 Bel-First database by Bureau Van Dijk which contains financial information of all Belgian firms.

\section{The adoption of formal compensation practices in SMEs: development of the Formal}

\section{Compensation Practices Scale}

As indicated above, this study considers formal compensation practices as practices that have identifiable rules, policies and regulations that are documented and integrated into the family firm. Informal compensation practices are characterized by decisions made on a personal case-by-case basis (Nguyen \& Bryant, 2004). In order to test the hypotheses that were formulated in the previous section, the method of Nguyen and Bryant (2004) was adopted, but modified for compensation practices instead of general HRM practices. That is, the formality of compensation practices was measured by asking the CEO what formal compensation practices they currently use. More specifically, the questionnaire contains seven items of formalization of the compensation system that are derived from the literature, which are discussed consecutively below. Afterwards, these six items were equally weighted and summed to create a 0 to 7 scale to measure the level of formality of compensation practices. The items were coded as 'formal' when the practice in question was present. The Formal Compensation Practices Scale used in this study is composed of the following items:

Presence of an HR Officer. When firms have appointed an HR Officer, this can be considered as an indicator of professionalization of the HRM -and thus also of the compensation- function (Wright et al., 2011).

Written compensation policy. When SMEs want to formalize their compensation function, Aronoff et al. (2011) advise them to establish a written compensation policy. Additionally, Berger and Berger (2001) mention that a valid and credible compensation system is based on a documented compensation strategy. The respondents were asked whether their firm had implemented a written compensation policy for managers and for employees other than management.

Benchmarking. Using an objective basis to setting pay is essential for developing a consistent compensation policy (Aronoff et al., 2011; Berger \& Berger, 2001). In addition, the Code Buysse II (2009), the Belgian corporate governance code for non-listed firms, indicates that compensation in these firms must be conform to the market and form the basis for attracting 
the best professionals. In the questionnaire, respondents were asked whether they use some sort of benchmarking to assess their compensation policy in relation to their competitors.

Compensation issues in the Board of Directors. As a best practice, compensation matters are discussed in the board, and major changes to executive compensation are made only with the board's approval (Aronoff et al., 2011). In the Belgian context, the Code Buysse II (2009), indicates that the board should determine the compensation for managers. However, this code only consists of recommendations and is subject to voluntary application of the rules (i.e. principle of self-regulation).

Compensation Committee. A compensation committee is a proven tool for making compensation decisions and to act as a management-development aid (Barrett, 2001). As from 2009, Code Buysse II, advises firms to establish such a committee. The tasks of such a committee should be to advise the board concerning compensation issues for senior management. The Code Buysse II (2009) explicitly mentions that a compensation committee can be especially valuable in family firms, as it facilitates the discussion over compensation for family members.

Family governance practices. Whereas nonfamily business only can install the formal compensation practices as described above, family businesses can use an additional tool: family governance practices. Their main goal is to promote communication among the family shareholders (Brenes et al., 2011; Poza, 2013). Two family governance practices are known to be very useful in developing a compensation policy for family firms: a family forum (also referred to as family council or family meeting) and a family charter (also referred to as family code of conduct or family constitution) (Aronoff et al., 2011; Poza, 2013). A firm is therefore assigned a score of 1 if it has established a family forum and/or charter and uses it explicitly to discuss compensation issues.

\section{Variables}

\section{Dependent variable}

The dependent variable is FCP-SCORE. So as to assign a FCP-score to each firm, the sum of the scores of the relevant dichotomous items (best practices) of the FCP scale as discussed above, is used. This approach is similar to the one used in many other studies (e.g. Astrachan \& Kolenko, 1994; Kim \& Gao, 2010; La Porta et al., 1998; Nguyen \& Bryant, 2004). The FCP-score thus represents the degree of formalization of the compensation function of each SME with the minimum score of zero and a highest possible score of seven. 


\section{Independent variables}

The dummy variable FAMILY CEO equals one when the CEO is a member of the controlling family, and zero otherwise.

\section{Control variables}

The model includes a range of variables in order to control for their potential effect on the formalization of compensation practices.

Although this study only focuses on the group of small and medium-sized firms, FIRM SIZE was included as a control variable. After all, the size of a firm can influence the level of formal and sophisticated HRM practices (Guthrie, 2001; Kim \& Gao, 2010). For example, the use of formal compensation practices may differ between firms with 10 and those with 99 employees. Large firms can be expected to be more complex, and thus might need more formal HRM (and thus also compensation) practices than smaller firms (Barrett \& Mayson, 2007). Yet, previous studies did not find consistent empirical results: while some found a significant positive effect of firm size on the use of formal HRM practices (e.g. De Kok \& Uhlaner, 2001; Newman \& Sheikh, 2014; Nguyen \& Bryant, 2004; Wu et al., 2014), others find no significant influence of firm size (e.g. Golhar \& Deshpande, 1997; Sels et al., 2006). Firm size was measured as the number of employees. Because the distribution was positively skewed, it was transformed using a natural logarithm for the statistical analysis.

As firms evolve from the start-up through the growth to the maturity life cycle phase, the complexity of their operations increase, as well as the necessity for more formal compensation systems. Contrary, younger firms can be considered as more open-minded and up-to-date with the latest trends in HRM practices. Previous studies found a significant negative effect of firm age on the use of performance-related pay and formal education programmes for new employees (Newman \& Sheikh, 2014), on the use of formal HR practices (Nguyen and Bryant, 2004) and on variable pay practices (Kim \& Gao, 2010). Therefore, the variable FIRM AGE, measured via the number of years since start-up, is included in order to control for the maturity of the firm.

Next, the model controls for the industry in which a firm is active. Following previous studies (Kim \& Gao, 2010; Newman \& Sheikh, 2014), a dummy variable INDUSTRY is included which equals one when a firm operates in the manufacturing industry, and zero otherwise.

As a CEO's human capital may influence development of HRM in SMEs (Mayson \& Barrett, 2006), the model controls for a CEO's education education. Previous research 
indicated that CEOs who are more capable and willing to adopt HRM best practices, are CEOs with a higher education level (Hannon \& Atherton, 1998, Newman \& Sheikh, 2014). CEO EDUCATION is operationalized via a dummy variable which equals one when the CEO has completed a university degree, and zero otherwise.

Finally, establishing formal compensation practices requests a number of resources that might be lacking in some SMEs. Therefore, the variable FIRM PERFORMANCE is added as a control variable (measured via return on assets in 2010).

\section{Results and discussion}

\section{Descriptive statistics}

Table 1 below presents the general characteristics of the firms and their CEOs in the sample. The average (median) sample firm has about 44 (28) employees and is 39 (31) years old. Almost eighty-five (85) percent of all firms in our final sample are led by a family CEO. The average CEO in our sample is 49 years old, has a university degree in $88 \%$ of the cases. and is male in $93 \%$ of the cases.. Table 2 presents a more detailed description of the sizes of the sample firms.

Insert Table 1 about here

Insert Table 2 about here

Table 3 presents an overview of the items on which the formal compensation practices score (FCP-SCORE) is composed. A nonparametric Mann-Whitney test gives a first indication of the differences on the adoption of the individual best practices and on the total score between family firms with a family CEO and those with a nonfamily CEO.

For the first item, Table 3 indicates that more than half (53\%) of the family firms have appointed a full-time HR manager. When we look at the differences within the group of family 
firms, we see that firms with a nonfamily CEO have appointed an HR manager significantly more often than those with a family CEO. Next, in about $30 \%$ of the family firms, a written compensation policy for managers is available and in $46 \%$ of the family firms a written compensation policy for employees that do not belong to the management team is established. This result is in line with that of Kotey and Slade (2005), who find that HRM practices are less formal for managers than for lower-level employees in small firms. Firms with a nonfamily CEO have significantly more often a written compensation policy for managers than firms with a family CEO. The establishment of a written compensation policy for employees other than management not significantly differs between family and nonfamily CEO. Thus, although firms with a nonfamily CEO appoint an HR Officer more often than firms with a family CEO do, it results in more written compensation policies for employees only.

The fourth best practice is the use of benchmarking tools as a basis for compensation decisions. As indicated in Table 3, about $46 \%$ of the family businesses use benchmarking: $41 \%$ of the firms with a family CEO and $70 \%$ of the firms with a nonfamily CEO. This difference is significant.

Next, the results indicate that $27 \%$ of the family firms with a family CEO and $50 \%$ of the family firms with a nonfamily CEO discuss general compensation issues in their board of directors (difference is significant). The Belgian corporate governance code for privately-held firms (2009) adds that compensation policy should be discussed by preference at the suggestion of a compensation committee. Therefore, the last 'best practice' is the establishment of a compensation committee. While only $8 \%$ of the family firms with a family CEO have established such a committee, $30 \%$ of the family firms with a nonfamily CEOs did (difference signficiant). The overall average of $11.8 \%$ is very similar to the $12 \%$ in the sample of Baeten and Decocker (2007), whose sample also consisted of Flemish family businesses. Thus, although the corporate governance code for privately-held firms clearly indicates the necessity and the usefulness of a compensation committee, the minority of the Belgian family SMEs have actually established one.

Even less family firms use family governance practices (family forum or family charter) to discuss compensation issues: $8 \%$ of the firms with a family CEO and $15 \%$ of the firms with a nonfamily CEO (difference non-significant).

As shown in Table 3, the sample family SMEs adopted on average 2.67 out of 7 possible formal compensation practices: 2.10 for family CEOs and 3.6 for nonfamily CEOs. This difference is significant, which gives a first indication that the adoption of formal compensation practices by firms with family CEOs might differ from that of firms with nonfamily CEOs. 
About $80 \%$ of the sample firms have adopted at least one practice, and thus $20 \%$ of the sample firms have not implemented any of the examined formal compensation practices.

Insert Table 3 about here

Table 4 shows the means and standard deviations, together with the correlation matrix pertaining to the variables used in the testing of the hypotheses. The univariate results show that the sample family firms with a nonfamily CEO are on average larger, higher educated, and worse performing as compared to firms with a family CEO. The table also shows that NONFAMILY CEO correlates significantly positive with FCP-SCORE which again gives a univariate indication on the outcome of the hypothesis.

Ordinary Least Squares (OLS) multiple regression was chosen as the appropriate statistical technique for model estimation in the paper. Although the correlation matrix shows no high correlations among the variables, Variance Inflation Factors (VIFs) are calculated to ensure that the results are not affected by possible multicollinearity. The maximum VIF is 1.50 , which is well below the threshold value of 10 above which multicollinearity might be an issue (Hair et al., 2006). In order to ease heteroscedasticity concerns, robust standard errors will be used. To meet the normality assumption underlying regression models, the variable FIRM SIZE is measured by the log-transformed number of employees.

Insert Table 4 about here

\section{Regression analyses}

When examining the control variables, a positive significant effect of FIRM SIZE on FCP-SCORE is shown. That is, larger family firms seem to employ more formal compensation practices than smaller firms. This is in line with many other studies who find that size is an important factor for the adoption of HR practices (for an overview, see Kim \& Gao, 2010): large firms tend to employ a more formal and standardized HR (and thus also compensation) system, as compared to smaller firms. This can be explained by economies of scale of larger 
firms (Gooderham et al., 1999), or by the informal nature of smaller firms (Hill \& Stewart, 2000). We find no significant direct relationship between FIRM AGE and the FCP-SCORE of a firm. Thus, older family firms not necessarily have a more formal compensation function. This is in line with the findings of Rutherford et al. (2003), who suggest that the occurrence of HR problems (and, consequently, HR practices) is not related to firm age. CEO education has a significant positive influence on FCP-SCORE: family firms with a CEO that has obtained a university degree establishes a higher number of formal compensation practices. FIRM PERFORMANCE appears to have no influence on the adoption of formal compensation practices in family firms. This rules out the assumption that the establishment of formalized procedures might depend on the performance (and thus, financial resources available) of the family firm. Finally, the INDUSTRY in which a family firm operates seems to have no significant influence on the level of formal compensation practices applied by a firm.

In order to test the Hypothesis, which compares the level of FCP of firms led by a family CEO and by a nonfamily CEO, Model 2 (Table 5) includes the variable NONFAMILY CEO. Its significant positive coefficient supports the hypothesis. Thus, family firms with a nonfamily CEO adopt significantly more formal compensation practices than their counterparts that are led by a family CEO. This finding therefore supports earlier studies who associate a nonfamily CEO to a professionalized family firm (in this study: professionalization of the compensation function). Whereas family CEOs are more often associated with informal, potentially nepotistic, compensation systems, an external CEO may recognize the need of a family firm to formalize the compensation system in order to stay competitive and attract and keep good employees.

Insert Table 5 about here

In order to test the robustness of these results, two additional regressions were performed. First, an additional control variable is entered into the model; $C E O$ SINGLEOWNER, which is a dummy variable that equals one when the CEO is the only shareholder of the firm, and zero otherwise. 6 cases were dropped because of missing values regarding the ownership structure of the firm. The results (presented in model 3 in Table 6) indicate that the results remain stable: even after controlling for single-owned firms, the variable NONFAMILY CEO has a significantly positive effect on FCP-SCORE. The second 
robustness test distinguishes between two types of family CEOs in order to check whether there is not only a difference between family and nonfamily CEOs, but also among the group of family CEOs. Model 4 (Table 6) includes the variables LONE-FAMILY CEO (dummy variable that equals one when the family CEO is the only family member in the management team) and MULTI-FAMILY CEO (dummy variable that equals one when there is at least one other family member present in the management team, besides the family CEO) (Combs et al., 2010). As indicated in Model 4, both coefficients of these new variables are negative and significant, meaning that they both are associated with a significantly lower level of formal compensation practices. A test of differences indicates that the coefficients of LONE-FAMILY CEO and MULTI-FAMILY CEO do not differ significantly from each other, confirming the idea that the group of family CEOs can be treated as homogeneous in this specific study.

Insert Table 6 about here

\section{Discussion and conclusion}

This study provides evidence into the actual application of common formal compensation practices in Flemish family SMEs, based on the 'best practices' as described in the literature. The results reveal that the majority of the family SMEs $(80 \%)$ have adopted at least one of the formal compensation practices we examined. The assignment of an HR Officer, the use of benchmarking for compensation issues, and the establishment of a written compensation policy for employees appear to be the most frequently implemented compensation practices. Despite recommendations in the corporate governance code for nonlisted firms, very few family firms have actually installed a compensation committee.

Next, as the differences within the group of family firms may potentially be even larger than the differences between family and nonfamily firms (Chua et al., 2012), this study takes into account this heterogeneity by introducing the CEO type as a contingency variable. The results indicate that family firms with a nonfamily CEO are associated with higher levels of formalization of the compensation function than their counterparts with a family CEO. This result support previous research which associates a nonfamily CEO to more professional 
management (e.g. Berenbeim, 1990; Bloom \& Van Reenen, 2007; Daily \& Dollinger, 1992; Gulbrandsen, 2005).

The practical implications of this research point to the fact that family firms with a nonfamily CEO can be considered to be more formalized than family firms with a family CEO as far as compensation practices are concerned. However, more formal compensation practices may not always be better for the firm. As the informal nature of SMEs can sometimes be considered as a competitive advantage (Sirmon \& Hitt, 2003), formalizing may not always be advantageous for the firm. We therefore suggest family business managers to carefully select those formal compensation practices that would benefit the firm the most. This also provides an opportunity for future research in order to investigate the impact of the amount of formal compensation practices on various outcomes such as, for example, family firm longevity or growth.

This study is subject to some limitations, which provide other opportunities for future research. First, generalizing the findings of this study must be taken with care, as the findings from this study are based on a cross-sectional sample of SMEs in one country, Belgium. However, recent papers investigating HRM practices in SMEs focus on the Chinese context (Kim \& Gao, 2010; Newman \& Sheikh, 2014), so a study focusing on a Western-European country might be an interesting point of reference for future research. Obviously, expanding the sample size and the geographical area would be interesting and beneficial in developing our knowledge of formal compensation practices in SMEs. Future research will therefore benefit from a larger sample, preferably covering multiple years.

Next, although the predictions originating from both the ability arguments and agency theory are the same, and they are confirmed by the results of this study (family firms with nonfamily CEOs adopt more formal compensation practices than those with family CEOs), the underlying mechanisms are very different. Investigating the possible explanations for the lack of use of formal compensation practices in family firms led by a family CEO (i.e. ability or agency arguments) will open up important avenues for future research.

Although the best practices in this study were carefully selected based on the available literature, it is possible that the findings will be sensitive to the selection of the practices investigated. Thus, future research investigate more, or other, formal compensation practices in their analyses, apart from the best practices used in this study. Also more detailed information on the costs and benefits of implementing formal compensation practices would be helpful to SMEs so they could determine which would be more effective for which type of SME. Also the mere binary assessment of the use of formal compensation practices should be 
fine-tuned in future research. After all, formal and informal HR practices are not two discrete choices, but rather two end of a continuum from formal to informal (Nguyen \& Bryant, 2004). Future researchers are also encouraged to consider the use of technology to back formal compensation systems, because a lack of technological expertise could influence the decision to implement formal management practices (Cooper et al., 2005). 


\section{References}

Aronoff, C. E., McClure, S. L., and Ward, J. L. (2011). Family business compensation. NY: Palgrave MacMillan.

Astrachan, J. H. (2010). Strategy in family business: Toward a multidimensional research agenda, Journal of Family Business Strategy, 1(1): 6-14.

Astrachan, J. H., and Kolenko, T. A. (1994). A neglected factor explaining family business success: Human resource practices, Family Business Review, 7(3): 251-262.

Astrachan, J. H., and Shanker, M. C. (2003). Family businesses' contribution to the US economy: A closer look, Family Business Review, 16(3): 211-219.

Baeten, X., and Dekocker, V. (2007). Verloning in familiebedrijven, Leuven-Gent: Vlerick Management School.

Barrett, J. E. (2001). Why form a ompensation committee? In B. Spector (Ed.), The Family Business Compensation Handbook (pp. 135-136). Philadelphia, PA: Family Business Publishing Co. .

Barrett, R., \& Mayson, S. (2007). Human resource management in growing small firms. Journal of Small Business and Enterprise Development, 14(2), 307-320.

Bartram, T. (2005). Small firms, big ideas: The adoption of human resource management in Australian small firms, Asia Pacific Journal of Human Resources, 43(1): 137-154.

Bennedsen, M., Pérez-González, F., \& Wolfenzon, D. (2007). Do CEOs Matter? (No. 132007). Copenhagen Business School, Department of Economics.

Berent-Braun, M., and Uhlaner, L. (2012). Family governance practices and teambuilding: paradox of the enterprising family, Small Business Economics, 38(1): 103-119.

Berger, L. A., and Berger, D. R. (2001). Human resources strategy for the family firm. In B. Spector (Ed.), The Family Business Compensation Handbook (pp. 34-36). Philadelphia, PA: Family Business Publishing Co.

Berenbeim, R. E. (1990). How business families manage the transition from owner to professional management. Family Business Review, 3(1), 69-110.

Bertrand, M., \& Schoar, A. (2006). The role of family in family firms. The Journal of Economic Perspectives, 20(2), 73-96.

Bloom, N., \& Van Reenen, J. (2007). Measuring and explaining management practices across firms and countries, Quarterly Journal of Economics, 122(4): 1351-1408. 
Brenes, E. R., Madrigal, K., \& Requena, B. (2011). Corporate governance and family business performance. Journal of Business Research, 64(3), 280-285

Cardon, M. S., and Stevens, C. E. (2004). Managing human resources in small organizations: What do we know?, Human Resource Management Review, 14(3): 295-323.

Carlson, D. S., Upton, N., and Seaman, S. (2006). The Impact of Human Resource Practices and Compensation Design on Performance: An Analysis of Family- Owned SMEs, Journal of Small Business Management, 44(4): 531-543.

Carrasco-Hernandez, A., and Sanchez-Marin, G. (2007). The determinants of employee compensation in family firms: empirical evidence, Family Business Review, 20(3): 215-228.

Chua, J. H., Chrisman, J. J., \& Bergiel, E. B. (2009). An agency theoretic analysis of the professionalized family firm. Entrepreneurship Theory and Practice, 33(2), 355-372

Chua, J. H., Chrisman, J. J., Steier, L. P., \& Rau, S. B. (2012). Sources of heterogeneity in family firms: An introduction. Entrepreneurship Theory and Practice, 36(6), 11031113.

Chrisman, J. J., Chua, J. H., Kellermanns, F. W., \& Chang, E. P. (2007). Are family managers agents or stewards? An exploratory study in privately held family firms. Journal of Business research, 60(10), 1030-1038

Code Buysse II (2009). Cororate Governance Recommendations for Non-listed Enterprises. Available at: www.codebuysse.com

Combs, J. G., Penney, C. R., Crook, T. R., \& Short, J. C. (2010). The impact of family representation on CEO compensation. Entrepreneurship Theory and Practice, 34(6), $1125-1144$

Cruz, C., Firfiray, S., and Gomez-Mejia, L. R. (2011). Socioemotional Wealth and Human Resource Management (HRM) in Family-Controlled Firms, Research in personnel and human resources management, 30: 159-217.

Cruz, C. C., Gómez-Mejia, L. R., \& Becerra, M. (2010). Perceptions of benevolence and the design of agency contracts: CEO-TMT relationships in family firms. Academy of Management Journal, 53(1), 69-89

Daily, C. M., and Dollinger, M. J. (1992). An empirical examination of ownership structure in family and professionally managed firms, Family Business Review, 5(2): 117-132.

Dekker, J. C., Lybaert, N., Steijvers, T., Depaire, B., \& Mercken, R. (2013). Family Firm Types Based on the Professionalization Construct Exploratory Research. Family Business Review, 26(1), 81-99. 
De Kok, J., \& Uhlaner, L. M. (2001). Organization context and human resource management in the small firm. Small Business Economics, 17(4), 273-291.

De Kok, J. M. P., Uhlaner, L. M., and Thurik, A. R. (2006). Professional HRM practices in family owned-managed enterprises, Journal of Small Business Management, 44(3): 441-460.

Dyer, W. G. (2003). The Family: The Missing Variable in Organizational Research\$, Entrepreneurship Theory and Practice, 27(4): 401-416.

Eddleston, K. A., Kellermanns, F. W., and Sarathy, R. (2008). Resource configuration in family firms: Linking resources, strategic planning and technological opportunities to performance, Journal of Management Studies, 45(1): 26-50.

Fama, E. F., \& Jensen, M. C. (1983). Separation of ownership and control.Journal of law and economics, 301-325.

Graham, J. R., and Harvey, C. R. (2001). The theory and practice of corporate finance: Evidence from the field, Journal of Financial Economics, 60(2): 187-243.

Graham, M. E., Murray, B., and Amuso, L. (2002). Stock-related rewards, social identity, and the attraction and retention of employees in entrepreneurial SMEs, Managing people in entrepreneurial organizations, 5: 107-145.

Golhar, D. Y., \& Deshpande, S. P. (1997). HRM practices of large and small Canadian manufacturing firms. journal of small business management, 35(3), 30.

Gomez-Mejia, L. R., Nunez-Nickel, M., \& Gutierrez, I. (2001). The role of family ties in agency contracts. Academy of management Journal, 44(1), 81-95

Gooderham, P. N., Nordhaug, O., \& Ringdal, K. (1999). Institutional and rational determinants of organizational practices: Human resource management in European firms. Administrative Science Quarterly, 44(3), 507-531

Guthrie, J. P. (2001). High-involvement work practices, turnover, and productivity: Evidence from New Zealand. Academy of management Journal,44(1), 180-190.

Hair, J. F., Anderson, R. E., Tatham, R. L., and Black, W. C. (2006). Multivariate analysis, Prentice-Hall, London.

Hall, A., \& Nordqvist, M. (2008). Professional management in family businesses: Toward an extended understanding. Family Business Review,21(1), 51-69.

Hannon, P. D., \& Atherton, A. (1998). Small firm success and the art of orienteering: the value of plans, planning, and strategic awareness in the competitive small firm. Journal of Small Business and Enterprise Development,5(2), 102-119. 
Harris, L. C., \& Ogbonna, E. (2007). Ownership and Control in Closely-held Family-owned Firms: An Exploration of Strategic and Operational Control.British Journal of Management, 18(1), 5-26.

Hayton, J. C. (2003). Strategic human capital management in SMEs: an empirical study of entrepreneurial performance, Human Resource Management, 42(4): 375-391.

Heneman, R. L., Tansky, J. W., and Camp, S. M. (2000). Human resource management practices in small and medium-sized enterprises: Unanswered questions and future research perspectives, Entrepreneurship Theory and Practice, 25(1): 11-26.

Hill, R., and Stewart, J. (2000). Human resource development in small organizations, Journal of European Industrial Training, 24(2/3/4): 105-117.

Hornsby, J. S., and Kuratko, D. F. (1990). Human resource management in small business: critical issues for the 1990s, Journal of Small Business Management, 28(3): 9-18.

Hornsby, J. S., \& Kuratko, D. F. (2003). Human resource management in US small businesses: A replication and extension. Journal of Developmental Entrepreneurship, 8(1), 73.

Jensen, M. C., \& Meckling, W. H. (1976). Theory of firm - managerial behavior, agency costs and ownership structure, Journal of Financial Economics, 3(4): 305-360.

Kanuk, L., and Berenson, C. (1975). Mail surveys and response rates: A literature review, Journal of Marketing Research: 440-453.

Kim, Y., and Gao, F. Y. (2010). An empirical study of human resource management practices in family firms in China, The International Journal of Human Resource Management, 21(12): 2095-2119.

Kotey, B., and Slade, P. (2005). Formal human resource management practices in small growing firms*, Journal of Small Business Management, 43(1): 16-40.

La Porta, R., Lopez-de-Silanes, F., Shleifer, A., and Vishny, R. (1998). Law and Finance, Journal of Political Economy, 106(6): 1113-1155.

Ling, Y., and Kellermanns, F. W. (2010). The effects of family firm specific sources of TMT diversity: The moderating role of information exchange frequency, Journal of Management Studies, 47(2): 322-344.

Marlow, S. (2002). Regulating labour management in small firms. Human Resource Management Journal, 12(3), 25-43.

Marlow, S., \& Patton, D. (2002). Minding the gap between employers and employees: the challenge for owner-managers of smaller manufacturing firms.Employee Relations, 24(5), 523-539. 
McCann, J. E., Leon Guerrero, A. Y., and Haley Jr, J. D. (2001). Strategic goals and practices of innovative family businesses, Journal of Small Business Management, 39(1): 50-59.

Michiels, A., Voordeckers, W., Lybaert, N., and Steijvers, T. (2013). CEO compensation in private family firms: the moderating role of ownership and management, Family Business Review, 26(2): 140-160.

Michiels, A., Voordeckers, W., Lybaert, N., and Steijvers, T. (2015). Dividends and family governance practices in family firms, Small Business Eonomics, 44: 299-314.

Miller, D., Lee, J., Chang, S., \& Le Breton-Miller, I. (2009). Filling the institutional void: The social behavior and performance of family vs non-family technology firms in emerging markets. Journal of International Business Studies, 40(5), 802-817.

Miller, D., Minichilli, A., \& Corbetta, G. (2013). Is family leadership always beneficial?. Strategic Management Journal, 34(5), 553-571.

Miller, D., Breton-Miller, L., Minichilli, A., Corbetta, G., \& Pittino, D. (2014). When do nonfamily CEOs outperform in family firms? Agency and behavioural agency perspectives. Journal of Management Studies, 51(4), 547-572.

Myers, S. C. (1977). Determinants of corporate borrowing. Journal of financial economics, 5(2), 147-175.

Neubauer, F. F., and Lank, A. G. (1998). The family business: Its governance for sustainability (Vol. 29): Routledge.

Newman, A., \& Z. Sheikh, A. (2014). Determinants of best HR practices in Chinese SMEs. Journal of Small Business and Enterprise Development, 21(3), 414-430.

Nguyen, T. V., \& Bryant, S. E. (2004). A study of the formality of human resource management practices in small and medium-size enterprises in Vietnam. International small business journal, 22(6), 595-618.

Nordqvist, M., Sharma, P., \& Chirico, F. (2014). Family firm heterogeneity and governance: A configuration approach. Journal of Small Business Management, 52(2), 192-209.

Oppenheim, A. N. (2000). Questionnaire design, interviewing and attitude measurement: Continuum Intl Pub Group.

Poza, E. J. (2013). Family business. Cengage Learning.

Reid, R. S., and Adams, J. S. (2001). Human resource management-a survey of practices within family and non-family firms, Journal of European Industrial Training, 25(6): 310-320. 
Reid, R., Morrow, T., Kelly, B., \& McCartan, P. (2002). People management in SMEs: an analysis of human resource strategies in family and non-family businesses. Journal of Small Business and Enterprise Development, 9(3), 245-259.

Rutherford, M. W., Buller, P. F., and McMullen, P. R. (2003). Human resource management problems over the life cycle of small to medium- sized firms, Human Resource Management, 42(4): 321-335.

Sels, L., De Winne, S., Delmotte, J., Maes, J., Faems, D., and Forrier, A. (2006). Linking HRM and small business performance: An examination of the impact of HRM intensity on the productivity and financial performance of small businesses, Small Business Economics, 26(1): 83-101.

Sharma, P. (2004). An overview of the field of family business studies: Current status and directions for the future, Family Business Review, 17(1): 1-36.

Sheehan, M. (2014). Human resource management and performance: Evidence from small and medium-sized firms. International Small Business Journal,32(5), 545-570.

Sirmon, D. G., \& Hitt, M. A. (2003). Managing resources: Linking unique resources, management, and wealth creation in family firms. Entrepreneurship theory and practice, 27(4), 339-358.

Sonfield, M. C., \& Lussier, R. N. (2009). Non-family-members in the family business management team: a multinational investigation. International entrepreneurship and management journal, 5(4), 395-415.

Songini, L. (2006). 15 The professionalization of family firms: theory and practice. Handbook of research on family business, 269.

Stewart, A., \& Hitt, M. A. (2012). Why can'ta family business be more like a nonfamily business? Modes of professionalization in family firms. Family Business Review, 25(1), 58-86.

Wallace, R. S. O., and Mellor, C. (1988). Nonresponse bias in mail accounting surveys: a pedagogical note, The British Accounting Review, 20(2): 131-139.

Westhead, P., and Cowling, M. (1998). Family firm research: The need for a methodological rethink, Entrepreneurship Theory and Practice, 23: 31-56.

Wilkinson, A. (1999). Employment relations in SMEs. Employee relations,21(3), 206-217.

Wright, P. M., Boudreau, J. W., Pace, D. A., Sartain, E. L., McKinnon, P., and Antoine, R. L. (2011). The chief HR officer: Defining the new role of human resource leaders. San Francisco, CA: John Wiley and Sons. 
Wu, N., Bacon, N., \& Hoque, K. (2014). The adoption of high performance work practices in small businesses: the influence of markets, business characteristics and HR expertise. The International Journal of Human Resource Management, 25(8), 11491169.

Zona, F. (2016). CEO leadership and board decision processes in family-controlled firms: comparing family and non-family CEOs. Small Business Economics, 47(3), 735-753. 


\section{TABLES}

Table 1.

General sample characteristics

\begin{tabular}{ll} 
Firm Characteristics & Mean \\
\hline Firm size & 44.05 employees \\
Firm age & 39.60 years \\
Manufacturing industry & $38.71 \%$ \\
ROA & $5.92 \%$ \\
\hline CEO Characteristics & Mean \\
\hline CEO age & 49.2 years \\
CEO gender & $93 \%$ male \\
CEO higher education & $87.90 \%$ \\
Family CEO & $84.68 \%$ \\
\hline
\end{tabular}

Note. $\mathrm{N}=124$ 
Table 2.

Sample description: employees

\section{Frequency}

Up to 15 employees

39

56

11

18

124

From 16 to 50 employees

From 50 to 100 employees

Over 100 employees

Total

\section{Percent}

$31.45 \%$

$14.56 \%$ 
Table 3.

Formal compensation practices scale

\begin{tabular}{|c|c|c|c|c|}
\hline & Mean & $\begin{array}{l}\text { Family firms with } \\
\text { a Family CEO }\end{array}$ & $\begin{array}{l}\text { Family firms with } \\
\text { a Nonfamily CEO }\end{array}$ & $\begin{array}{c}\text { Mann-Whitney } \\
\text { test } \\
\text { (z-value) }\end{array}$ \\
\hline 1.The firm has appointed a full-time HR Manager & $53.54 \%$ & $48.60 \%$ & $80.00 \%$ & $2.58 * *$ \\
\hline 2.The firm has a written compensation policy for managers & $29.13 \%$ & $24.30 \%$ & $55.00 \%$ & $2.76 * * *$ \\
\hline 3.The firm has a written compensation policy for employees other than managers & $46.46 \%$ & $43.93 \%$ & $60.00 \%$ & 1.32 \\
\hline 4.The firm makes use of benchmarking tools for compensation decisions & $45.67 \%$ & $41.41 \%$ & $70.00 \%$ & $2.37 * *$ \\
\hline 5.Compensation issues are discussed in the board & $30.71 \%$ & $27.10 \%$ & $50.00 \%$ & $2.03 * *$ \\
\hline 6.The firm has established a compensation committee & $11.81 \%$ & $8.41 \%$ & $30.00 \%$ & $2.74 * * *$ \\
\hline $\begin{array}{l}\text { 7. The firm has established a family forum and/or charter and uses it to discuss } \\
\text { compensation issues }\end{array}$ & $9.45 \%$ & $8.41 \%$ & $15.00 \%$ & 0.92 \\
\hline Mean FCP-SCORE & 2.67 & 2.10 & 3.60 & $3.43 * * *$ \\
\hline
\end{tabular}

Note: percentages denote proportion of firms that has implemented this compensation practice;

Family firms with a family CEO: N=104; Family firms with a nonfamily CEO : N=20 
Table 4.

\section{Summary data and Pearson correlations}

\begin{tabular}{|c|c|c|c|c|c|c|c|c|}
\hline & Mean & S.D. & 1 & 2 & 3 & 4 & 5 & 6 \\
\hline 1.FCP-SCORE & 2.29 & 1.80 & 1.00 & & & & & \\
\hline 2.FIRM AGE & 39.60 & 29.58 & .11 & 1.00 & & & & \\
\hline 3. FIRM SIZE ${ }^{A}$ & 3.25 & 1.03 & $.38 * * *$ & $.42 * * *$ & 1.00 & & & \\
\hline 4.CEO EDUCATION & 0.88 & 0.33 & .10 & .04 & -.07 & 1.00 & & \\
\hline 5.INDUSTRY & 0.39 & 0.49 & $.20 * *$ & $.19 * *$ & $.29 * * *$ & -.01 & 1.00 & \\
\hline 6.PERFORMANCE & 5.92 & 11.38 & .07 & -.06 & .04 & .04 & -.08 & 1.00 \\
\hline 7.NONFAMILY CEO & 0.15 & 0.36 & $.32 * * *$ & -.05 & $.31 * * *$ & $.16^{*}$ & .06 & $-.16^{*}$ \\
\hline
\end{tabular}

Notes. $\mathrm{N}=118 ;{ }^{\text {a }}$ natural logarithm; $* * *, * * *$ denotes significance at a probability level below $0.10,0.05$, and 0.01 , respectively. 
Table 5.

\section{Regression results}

\begin{tabular}{|c|c|c|}
\hline & $\begin{array}{l}\text { Model } 1 \\
\text { Control variables }\end{array}$ & $\begin{array}{l}\text { Model } 2 \\
\text { Full model }\end{array}$ \\
\hline Constant & $\begin{array}{l}-.4343 \\
(.5643)\end{array}$ & $\begin{array}{l}.0258 \\
(.5806)\end{array}$ \\
\hline \multicolumn{3}{|l|}{ Hypothesis } \\
\hline NONFAMILY CEO & & $\begin{array}{l}1.2347 * * \\
(.4832)\end{array}$ \\
\hline \multicolumn{3}{|l|}{ Controls } \\
\hline FIRM AGE & $\begin{array}{l}-.0048 \\
(.0053)\end{array}$ & $\begin{array}{l}-.0012 \\
(.0054)\end{array}$ \\
\hline FIRM SIZE $E^{A}$ & $\begin{array}{l}.6347 * * * \\
(.1428)\end{array}$ & $\begin{array}{l}.440 * * \\
(.1577)\end{array}$ \\
\hline CEO EDUCATION & $\begin{array}{l}.7339 * \\
(.4279)\end{array}$ & $\begin{array}{l}.4487 \\
(.4353)\end{array}$ \\
\hline FIRM PERFORMANCE & $\begin{array}{l}.0085 \\
(.0117)\end{array}$ & $\begin{array}{l}.0165 \\
(.0116)\end{array}$ \\
\hline INDUSTRY & $\begin{array}{l}.4053 \\
(.3316)\end{array}$ & $\begin{array}{l}.4544 \\
(.3278)\end{array}$ \\
\hline Model F-statistic & $7.15 * * *$ & $7.87 * * *$ \\
\hline Adjusted $R^{2}$ & $17.71 \%$ & $22.63 \%$ \\
\hline$N$ & 124 & 124 \\
\hline
\end{tabular}

Notes. Dependent variable $=$ FCP score; Hereoskedasticity-robust standard errors in parentheses; ${ }^{\text {a }}$ natural $\operatorname{logarithm;} *, * *, * * *$ denotes significance at a probability level below $0.10,0.05$, and 0.01 , respectively. 
Table 6.

Robustness tests

\begin{tabular}{|c|c|c|}
\hline & Model 3 & Model 4 \\
\hline Constant & $\begin{array}{l}-.1468 \\
(.6690)\end{array}$ & $\begin{array}{l}1.2369 \\
(.8924)\end{array}$ \\
\hline \multicolumn{3}{|l|}{ Hypothesis } \\
\hline NONFAMILY CEO & $\begin{array}{l}1.0418 * * \\
(.4344)\end{array}$ & \\
\hline LONE-FAMILY CEO & & $\begin{array}{l}-1.2823 * * \\
(.5696)\end{array}$ \\
\hline MULTI-FAMILY CEO & & $\begin{array}{l}-1.2195 * * \\
(.4852)\end{array}$ \\
\hline \multicolumn{3}{|l|}{ Controls } \\
\hline FIRM AGE & $\begin{array}{l}-.0035 \\
(.0053)\end{array}$ & $\begin{array}{l}-.0011 \\
(.0054)\end{array}$ \\
\hline FIRM SIZE & $\begin{array}{l}.5056 * * * \\
(.1596)\end{array}$ & $\begin{array}{l}.4558 * * * \\
(.1669)\end{array}$ \\
\hline CEO EDUCATION & $\begin{array}{l}.4467 \\
(.4475)\end{array}$ & $\begin{array}{l}.4482 \\
(.4362)\end{array}$ \\
\hline FIRM PERFORMANCE & $\begin{array}{l}.0194 * \\
(.0116)\end{array}$ & $\begin{array}{l}.0168 \\
(.0122)\end{array}$ \\
\hline INDUSTRY & $\begin{array}{l}.5168 \\
(.3378)\end{array}$ & $\begin{array}{l}.4575 \\
(.3303)\end{array}$ \\
\hline CEO SINGLEOWNER & $\begin{array}{l}.0579 \\
(.3913)\end{array}$ & \\
\hline Model F-statistic & $6.62 * * *$ & $6.74 * * *$ \\
\hline Adjusted $R^{2}$ & $23.11 \%$ & $22.66 \%$ \\
\hline$N$ & 118 & 124 \\
\hline
\end{tabular}

Notes. Dependent variable $=$ FCP score; Hereoskedasticity-robust standard errors in parentheses; ${ }^{\text {a }}$ natural $\operatorname{logarithm;} * * * * * *$ denotes significance at a probability level below $0.10,0.05$, and 0.01 , respectively. 